\title{
HVMANITAS
}

\section{O arcebispo de Braga D. Diogo de Sousa "Principe Umanizzato" do Renascimento e o seu projecto educativo moderno}
Autor(es):
Soares, Nair de Nazaré Castro Publicado por: $\begin{aligned} & \text { Faculdade de Letras da Universidade de Coimbra, Instituto de Estudos } \\ & \text { Clássicos }\end{aligned}$
URL persistente:
URI:http://hdl.handle.net/10316.2/23170
DOI:
DOI:http://dx.doi.org/10.14195/2183-1718_63_29

Accessed : $\quad$ 26-Apr-2023 03:25:18

A navegação consulta e descarregamento dos títulos inseridos nas Bibliotecas Digitais UC Digitalis, UC Pombalina e UC Impactum, pressupõem a aceitação plena e sem reservas dos Termos e Condições de Uso destas Bibliotecas Digitais, disponíveis em https://digitalis.uc.pt/pt-pt/termos.

Conforme exposto nos referidos Termos e Condições de Uso, o descarregamento de títulos de acesso restrito requer uma licença válida de autorização devendo o utilizador aceder ao(s) documento(s) a partir de um endereço de IP da instituição detentora da supramencionada licença.

Ao utilizador é apenas permitido o descarregamento para uso pessoal, pelo que o emprego do(s) título(s) descarregado(s) para outro fim, designadamente comercial, carece de autorização do respetivo autor ou editor da obra.

Na medida em que todas as obras da UC Digitalis se encontram protegidas pelo Código do Direito de Autor e Direitos Conexos e demais legislação aplicável, toda a cópia, parcial ou total, deste documento, nos casos em que é legalmente admitida, deverá conter ou fazer-se acompanhar por este aviso.

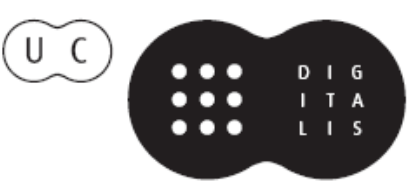


humanitas

Vol. LXIII

2011 


\title{
O ARCEBISPO DE BRAGA D. DIOGO DE SOUSA "PRINCIPE UMANIZZATO" DO RENASCIMENTO E O SEU PROJECTO EDUCATIVO MODERNO'
}

\author{
NaIr de Nazaré Castro Soares \\ Universidade de Coimbra
}

Prelado sem letras é ave sem penas, e navio sem leme, e relógio sem pesos. ${ }^{2}$

\section{Resumo}

D. Diogo de Sousa, Arcebispo e Senhor de Braga (1505-1532), "segundo fundador" desta cidade, realizou com firmeza uma síntese notável entre os elementos subjectivos e objectivos do episcopado, entre as qualidades evangélicas pessoais do "Bom Pastor", segundo o ideal humanista, e a estrutura interna episcopal, os seus poderes jurisdicionais, a sua consistência institucional, a sua estrutura hierárquica. Soube assim salvaguardar a dignidade e o ministério, dignitas et officium e exercer a sua magnanimitas e magnificentia: na sua função pastoral, na

${ }^{1}$ Dedico este estudo ao meu colega, desde o primeiro ano do Curso de Filologia Clássica da FLUC (1966-1967), José Ribeiro Ferreira - galardoado com a Medalha de Ouro da sua cidade, Santo Tirso, na Arquidiocese de Braga - e a sua mulher Maria José, aos quais me liga uma amizade fraternal, nunca esmorecida e sempre renovada, durante toda uma vida. Para ambos é este verso de Horácio, Sermones, 1. 5. 44: Nil ego contulerim iucundo sanus amico.

${ }^{2}$ Vide Frei Heitor Pinto 1952: 166. Na Imagem da vida cristã, cuja primeira parte saiu a lume em Coimbra, em 1563, Frei Heitor Pinto apresenta a expressão, em epígrafe, que é uma tradução adaptada do Songe de Vergier (I, 132) de Cristina de Pisano que, no século XV, escreve: "Un roy sans letture est comme un nef sans aviron et comme ung oiseau sans ales". 
sua actividade apostólica e reformadora, na sua obra legislativa, arquitectónica e urbanística, no seu mecenato e acção cultural, na sua preocupação em instruir o clero e todo o povo, no seu projecto educativo de fundar um colégio universitário em Braga, numa palavra, no exercício enérgico do seu "primado", na Igreja, e das suas virtudes de "principe umanizzato".

Palavras chave: Primeiro Humanismo, ideal humanista de episcopado, reforma do clero, projecto educativo em Braga (Colégio de São Paulo).

\section{Résumé}

D. Diogo de Sousa, Archévêque et Seigneur de Braga (1505-1532), "second fondateur" de cette ville, il opérait, fermement, une synthèse remarquable entre les caractères subjectifs et objectifs de l'épiscopat, entre les qualités évangéliques personnelles de "Bon Pasteur", selon l'idéal humaniste, et la structure interne épiscopale, ses pouvoirs juridictionnels, sa consistance institutionnelle, sa structure hiérarchique. Il a su, en effect, sauvegarder la dignité et le ministère, dignitas et officium et exercer sa magnanimitas et magnificentia: dans sa fonction pastorale, son activité apostolique et reformatrice, dans son oeuvre législatif, architectonique et urbanistique, dans son mécenat et action culturelle, dans son souci d'instruction du clergé et de tout le peuple, dans son project éducatif de fonder un collège universitaire à Braga, tout court, dans l'exercice énergique de son "primat" dans l'Église et de ses vertus de "principe umanizzato".

Mots clés: Premier Humanisme, l'idéal humaniste de l'épiscopat, réforme du clergé, project éducatif à Braga (Collège de Saint Paul).

D. Diogo de Sousa, Arcebispo e Senhor de Braga, durante vinte sete anos (1505-1532), considerado o "novo fundador" desta cidade, pela sua actividade pastoral, cultural e humanismo cívico, é uma personalidade de relevo, com interesse para a história da Igreja e para a história das ideias religiosas, sócio-políticas, pedagógicas e artísticas desta época - a do primeiro Humanismo em Portugal $^{3}$.

${ }^{3}$ Vide A. de Jesus Costa 1993: 17-119. Sobre as origens deste senhorio de Braga; a transferência da jurisdição da cidade e seu termo para a Coroa, em 1402; a sua devolução por D. Afonso V ao Arcebispo Luís Pires, em 12 de Março de 1472; e a firmeza de D. Diogo de Sousa, para acautelar e conservar essa jurisdição, nos reinados de D. Manuel e D. João III, vide José Marques 1997; Idem, in Jorge Coutino (coord.) 2006: 45-68. 
Conhecidos são os estudos analíticos e documentais atinentes à sua personalidade humana, à sua actividade apostólica e reformadora, à sua cultura, ao seu mecenato e benemerência, à sua magnificência de antístite, às suas múltiplas iniciativas inovadoras ${ }^{4}$. Estes aspectos, apesar de contemplados em estudos de notáveis investigadores, convidam-nos todavia a um novo olhar, de diferente perspectiva que, porventura, nos surpreenda com alguma novidade sobre a figura singular e fascinante de D. Diogo de Sousa.

Incidindo o nosso interesse sobre a imago principis do Arcebispo bracarense - a sua acção pastoral e reformadora, a sua acção governativa -, apraz-nos poder apreciar, à luz do ideário humanista, as manifestações pluriformes da personalidade de um prelado que, desde o limiar da Idade Moderna, dirige a Arquidiocese Primaz da Hispânia até à terceira década do século XVI, como um verdadeiro «principe umanizzato» do Renascimento.

Importa, todavia, enquadrar a figura de D. Diogo de Sousa na época que o viu nascer, que assistiu à sua formação, ao seu cursus honorum, e apreciar o "milagre" das suas realizações.

Nascido em Évora em 1461, fez os estudos elementares na sua terra natal e em Lisboa; cursou Cânones na Universidade de Salamanca e Teologia na de Paris. Em Salamanca, por certo, adquiriu a preparação em «todalas artes e sciencias que são necessárias à Teologia», para usar palavras suas, referentes ao seu projecto educativo na cidade de Braga. Terá provavelmente sido aluno de Élio António Nebrija - o introdutor do humanismo gramatical e filológico na Universidade helmantina, onde ensina e se empenha em expulsar a barbárie gótica, desde 1475 -, andava o futuro arcebispo de Braga pelos seus catorze anos ${ }^{5}$. Era esta a idade, em

${ }^{4}$ Cf. e. g. Dom Rodrigo da Cunha 1635 (ed. 1989); Monsenhor J. Augusto Ferreira 1931; A. da Costa Ramalho 1997: 83-105; J. S. da Silva Dias 1972; Idem 1960; José Marques 1997: 3-143; A. de Jesus Costa 1993: 17-119; Rui Maurício 2000; Jorge Coutinho (coord.) 2006.

5 À falta de livros de matrícula ou de graus, a presença dos portugueses é atestada apenas pelos livros dos conselhos escolares, pelo que se torna por demais lacunar. Vide Marques, A. J. 1996: 167-186.

Sobre Nebrija, o autor de Introductiones latinae (1481), e sobre o ensino na época em que D. Diogo de Sousa cursou Cânones em Salamanca, vide C. Codoñer 1994. No Estudo Salmantino, exercem o seu magistério o italiano Lucio Marineo Sículo, desde 1485, e o português Aires Barbosa, o mestre grego, desde 1495, que, a par de Nebrija, têm o seu quinhão na expulsão da barbárie, através do humanismo 
que, feitos os estudos elementares - a iniciação ao Latim, à Gramática, à Prosódia, a que andava associada a aprendizagem da leitura, da escrita e do cálculo -, se podia entrar na Faculdade de Artes, onde se prosseguia o estudo da Gramatica latina, da estilística, da métrica, mas sobretudo se estudava a Lógica e a Dialéctica, com vista a obter o primeiro grau universitário, o bacharelato em Artes $^{6}$.

A Universidade de Paris, catedral europeia da Teologia, apesar das resistências sorbónicas, tinha-se tornado permeável aos studia humanitatis, na altura em que D. Diogo de Sousa a frequentou, com mestres como Guillaume Fichet, Guillaume Tardif, Robert Gaugin, a que dariam continuidade Lefèvbre d'Étaples e Josse Clichtove?

Regressado a Portugal, na sua juventude, é já cónego da Sé de Évora, quando D. João II o nomeia para o cargo de Deão da Capela Real.

A viver na corte, tem oportunidade de frequentar as aulas de Cataldo Parísio Sículo e aperfeiçoar os seus conhecimentos de Retórica ${ }^{8}$. Ao jovem prelado manifesta o Humanista italiano estima e dedicação, nas quatro cartas e vinte e nove epigramas que lhe dirige, para lhe fazer confidências ou se valer dos seus préstimos?.

filológico. Com esta mesma intenção, Fernando de Manzanares compõe, em 1485, os Flores rhetorici, editados em Salamanca em 1488, que seguem as lições de Nebrija, na esteira das Elegantiae linguae latinae de Lorenzo Valla.

${ }^{6}$ A. Renaudet 1916, $2^{\mathrm{a}}$ ed. 1953: 26-28; Ch. Thurot 1850: 37-101. J.-P. Massaut 1968: 114 e sqq.

${ }^{7}$ De notar o eclectismo da ratio studiorum da Universidade de Paris, capital da Escolástica - nos anos de formação de Josse Clichtove, de 1470 a 1490: nela figuram as Elegantiae de Valla e os autores clássicos conhecem larga representação. Vide J.-P. Massaut 1968: 141-168; A. Renaudet 1916, $2^{\text {a }}$ ed. 1953: 87.

${ }^{8}$ Nos centros universitários europeus que frequentou e nos cursos em que se formou, adquiriu, sem sombra de dúvida, perícia em Artes, que se traduzia sobretudo no domínio correcto e elegante do latim, língua de pensamento e de expressão de todos os saberes, na sua época. A presença do Deão da Capela Real nos cursos de Cataldo, na corte, são uma prova dos seus interesses intelectuais e da obseruantia para com um mestre estrangeiro, da Itália, pátria do Humanismo. É este humanista que insiste em o ter como mediador de seus protectores e também como patronus. A competência linguística de D. Diogo de Sousa, a juntar à sua formação jurídica e teológica, teria contribuído para que D. João II e D. Manuel o tivessem escolhido para seu representante em duas embaixadas à Cúria romana.

${ }^{9}$ A. da Costa Ramalho 2010: 43; 121-125; 211-213; e 215. 
D. Diogo de Sousa torna-se uma das mais ilustres figuras do reino, ao desempenhar um proeminente papel em duas embaixadas à Cúria romana. A primeira embaixada, em que participou, foi em 1493, a de D. Fernando de Almeida, bispo eleito de Ceuta, que, em nome de D. João II, prestou obediência ao papa Alexandre VI, recentemente eleito. Permanece este Prelado em Itália por mais dois anos, período em que visita várias cidades e se demora em Roma e Florença. Nesta capital da Toscana, assiste ao auge das pregações de Girolamo Savonarola, o "profeta desarmado", no dizer de Maquiavel, que, desde 16 de Fevereiro de 1491, é pregador na "Duomo", a catedral de Santa Maria del Fiore, cuja nave pode acolher milhares de fiéis sob a cúpula prodigiosa de Brunelleschi. Savonarola, personagem carismática, na Florença dos Médicis, na Itália da Renascença, perturba os poderes instituídos, entra em conflito com Lourenço o Magnífico, combate o Papa Bórgia, Alexandre VI, e seduz, com o seu pensamento e espiritualidade, figuras como Giovanni Pico della Mirandola, Marsilio Ficino, Boticelli, Miguel Ângelo e o poeta-jurista português Henrique Caiado ${ }^{10}$.

Em 24 de Setembro de 1494, morre em Florença Angelo Poliziano, que regia no Studio a cadeira de Arte Poética e Oratória - mestre de um escol de Portugueses, e entre eles, os filhos de João Teixeira, em que avultam Luís Teixeira, mestre do futuro D. João III, Aires Barbosa, Martim de Figueiredo e o próprio Caiado. Decorridos alguns meses, em 22 de Fevereiro de 1495, Carlos VIII, rei de França, avança com o seu exército sobre Nápoles e põe em fuga o jovem rei Fernando II que, só em Julho, regressa à sua cidade. Perante a ameaça de Carlos VIII, as negociações de Pedro de Médicis com os franceses, para afastar o perigo, levam à sublevação dos florentinos que saquearam o palácio dos Médicis e destruíram a sua riqueza artística, acontecimento dolorosamente notado pelos humanistas.

Era este o panorama da Itália que D. Diogo de Sousa pôde contemplar!

Durante esta sua missão diplomática, D. Diogo de Sousa é nomeado Bispo do Porto, por bula de Alexandre VI, de 23 de Outubro de 1495, dois dias antes da morte de D. João II, ocorrida em Alvor-Algarve, no dia 25 deste mesmo mês.

D. Diogo de Sousa, na sua permanência em Itália, convive com Henrique Caiado - antigo aluno de Cataldo e de Angelo Poliziano -, o famoso poeta latino das Éclogas, elogiado por Erasmo. Caiado trata o

${ }^{10}$ Vide Pierre Antonetti 1991. 
jovem prelado D. Diogo de Sousa como seu mecenas: dedica-lhe vários epigramas e, a 11 de Julho de 1495, a Écloga $I^{11}$.

Num dos epigramanas que lhe dirige por ocasião da sua partida de Roma para ascender à cátedra episcopal portuense, Ad Iacobus Sousam Pontificem (2. 37), em humilde voz, faz uma prece a Deus - designado, à maneira clássica, com o atributo de Júpiter, Tonans - para que o faça pastor do seu rebanho, o eleve ao pontificado: Interea supplex humili rogo uoce Tonantem/ pastorem ut faciat te gregis ille sui ${ }^{12}$.

Em 1505, integra D. Diogo de Sousa uma outra embaixada, de homenagem e obediência a Júlio II, em nome do rei D. Manuel. Por ocasião da sua pernmanência em Roma, em 11 de Julho deste ano, foi nomeado Arcebispo de Braga, por renúncia de D. Jorge da Costa, tinha então quarenta e quatro anos ${ }^{13}$.

Era o século de ouro das cortes europeias e das cidades do Renascimento italiano que D. Diogo de Sousa conhecera em toda a sua grandeza! Era a época das embaixadas a Roma, que ele próprio integrou, e das respectivas orações de obediência, que davam notícia ao papa e ao auditório universal, que a Cúria romana então representava, das glórias da nação lusa, na época dos Descobrimentos.

${ }^{11}$ Ibidem. Nesta Écloga I, surge o elogio da Florença de Savonarola (vv. 108111), pouco conveniente, por ser seu dedicatário D. Diogo de Sousa, um diplomata do rei D. João II - com boas relações com a família dos Médicis - que acabava de prestar homenagem ao Papa Bórgia, Alexandre VI, pai de César Bórgia. Sem esquecer que Savonarola, pelas proporções que tomou a sua pregação e o seu ideal de Renouatio Ecclesiae, iria despertar a admiração de Lutero que pretende fazer dele um arauto da Reforma.

${ }^{12}$ Henricus Caiadus 1501; Pe. António P. dos Reis 1745: 51-259 (vol. I); A. Costa Ramalho 1997: 121-123. O estilo laudatório, em que se percebe o "jogo cortesão" humanista, que busca captar a atenção de um mecenas ou a protecção de uma família, adequa-se todavia ao merecimento, à cultura, à posição na hierarquia social do elogiado, ao carácter e personalidade da figura de D. Diogo da Sousa. Sobre este poema e o seu destinatário vide A. Costa Ramalho, ibidem.

${ }^{13}$ D. Diogo de Sousa é feito Arcebispo por bula de Júlio II, de 11 de Julho de 1505. Gil Vicente, no sermão pregado, em 1506, «ao muyto nobre Rey Dom Manuel», na noite do nascimento do infante D. Luís, refere-se ao ir arcebispar a Roma - «quierome yr a Roma, quiero aecebispar» (Copilaçam, CCLIII) -, numa alusão, muito provável, a este acontecimento, segundo A. Costa Ramalho 1997: 119-123. 
D. Manuel, o Venturoso, assistirá, no seu reinado, à chegada de Vasco da Gama à Índia, em 1498, e, em 1500, à descoberta do Brasil. As descobertas e as conquistas do novo mundo, naquilo que de grandioso e de exotismo encerravam, marcam toda uma geração de portugueses e também de estrangeiros, a quem as notícias chegavam, a partir de Roma, ou também pelo contacto directo com os nautas, em Lisboa ou na Flandres, ligadas por uma carreira regular de naus, duas vezes por ano, desde 1502. Assim acontece com Thomas More na criação do português Raphael Hithodeu, o herói da sua obra de alcance universal, a Utopia, publicada em Londres em $1516^{14}$.

Em Roma, desde os finais do Quattrocento, eram habituais as celebrações, por parte da cúria romana, dos feitos dos portugueses, que ganham universalidade pela luta contra os Turcos, um serviço prestado à Cristandade, que as orações de obediência enalteciam acima de tudo ${ }^{15}$.

Ficaram famosas, entre todas as embaixadas, a de $1481 \mathrm{em}$ que foi orador D. Garcia de Meneses ${ }^{16}$, a de D. Diogo de Sousa, em 1505, e a de Tristão da Cunha, em 1514, sendo o discurso de obediência destas últimas proferido por Diogo Pacheco ${ }^{17}$.

$\mathrm{Na}$ oração de 1505, o orator regius faz o elogio insistente da acção de D. Manuel e do próprio rei «mui prudente, justo e moderado Príncipe, o mais poderoso no nosso tempo entre os principais da religião cristã»; afirma que «com a sagaz indústria de D. Manuel, suas enormes despesas e seus mais fervorosos cuidados, penetrámos na Índia [...] E não só costeámos a Índia e a Etiópia, mas também as orlas marítimas do Golfo Arábico

${ }^{14}$ A obra de Vespuccio, Paesi nuovamente retrouati. Nouo Mondo da Alberico Vesputio Florentino intitulato (1507) foi traduzida para latim com o título Itinerarium Portugallensium e Lusitania in India et inde in Occidentem (1508).

${ }^{15}$ Todas estas orações, proferidas perante o papa, ou as cartas que lhe eram enviadas, a dar notícias das descobertas e conquistas ultramarinas, desde o reinado de D. Afonso V aos de D. João II e de D. Manuel, retomam sempre o mesmo motivo - a guerra contra os Turcos, a defesa e expansão da Fé cristã. Os Turcos já não são só os do no norte de África, mas os seguidores do Islão, nas paragens distantes do Índico e do Mar Vermelho.

16 "A Oração ao Sumo Pontífice Sisto IV" dita por D. Garcia de Meneses em 1481 figura na Chorografia de Gaspar Barreiros. Vide Martim de Albuquerque: 1988 (vol. 2).

${ }^{17}$ A embaixada de 1514 ficou conhecida pela pompa e exotismo da presença do elefante indiano, oferta do nosso monarca ao Sumo Pontífice Leão X. 
e do Golfo Pérsico e as costas do Mar Roxo, e circundámos quase todo o orbe», podendo «os cristãos esperar que em breve seja abolida toda a perfídia e heresia maomética». Enaltece a gesta lusa, que assume uma dimensão épica; inaugura a temática de uma Nova Idade do Ouro e, inspirando-se no livro VI da Eneida (vv. 790-795), faz de Júlio II um novo Augusto: «Eis Júlio, que é da raça dos deuses; ele recriará os séculos de oiro, e desde o Lácio, pelos campos onde outrora reinou Saturno, estenderá o seu império para além dos Garamantas e dos Índios» ${ }^{18}$.

Estas orações de obediência e as celebrações públicas de júbilo pelos grandiosos feitos lusos, com festas, procissões, missas solenes e pregações, bem como a divulgação pela imprensa romana das cartas da chancelaria portuguesa que davam notícia das conquistas ao infiel, em círculos mais restritos, contribuem para a criação de um mundo de fantasia, de utopia, que se reflecte nas letras e nas artes, de muitos autores nacionais, mas também estrangeiros, como Egidio da Viterbo, Giovanni Baptista Mantuano, Francesco Albertini, Albert Dürer, além de Thomas More.

Esta aura mítica que se criou em torno das façanhas dos portugueses, nas mais remotas paragens do globo, levou Egídio da Viterbo a afirmar, em 1507 - num sermão proferido em Roma nas festividades que Júlio Il promovera para celebrar as nossas vitórias no Oriente -, que nada desejava mais no mundo do que ser Português ${ }^{19}$. Neste mesmo ano, o carmelita Giovanni Baptista Mantuano faz o elogio rasgado das viagens marítimas dos portugueses, louva os seus progressos na ciência náutica, o seu papel na expansão e consolidação da Fé. Gil Vicente, no Auto da Fama, escrito em 1510, chama a D. Manuel «alferes da fé /e rei do mar» ${ }^{20}$.

${ }^{18}$ Oração de obediência ao Sumo Pontífice Júlio II dita por Diogo Pacheco em 1505 in Martim de Albuquerque 1988 (vol. 5): 16, 17 e 18.

19 Vide Sylvie Deswarte 1993: 126-150. Sobre o discurso de Egidio da Viterbo e sua importância, pela repercussão que teve nos temas que figuram na abóbada da Capela Sixtina e na Stanza della Segnatura de Rafael, Ibidem : 129131; Jean Delumeau 1997: 217-236; 491-493 - dedica um capítulo inteiro (cap. $\mathrm{X}$ ) ao milenarismo português, sendo cerca de uma dezena de páginas sobre "o sonho de Manuel, o venturoso", que projectava uma espécie de império universal e messiânico, sob a égide de Portugal.

${ }^{20}$ Vide a "Fala da Fama em diálogo com o Italiano", in Gil Vicente, ed. de José Camões 194 (vol. II). 
Este sentimento contagiante de entusiasmo pelas nossas Descobertas, pelo desconhecido, caldeado com o proselitismo cristão, que crê no estabelecimento de uma respublica christiana sob a égide de Portugal, aflora no imaginário dos mais diversos autores, nos anos subsequentes à grande aventura marítima do Gama. É esse mesmo sentimento o grande móbil do entusiasmo descritivo que percorre a literatura nacional, em latim e em vulgar.

No tempo de D. Manuel, chega-se ao epílogo dessa longa história de descobrir. Vive-se o fausto e o luxo da corte mais prestigiada da Europa, que sustenta a ociosidade e a mania nobiliárquica dos cortesãos, numa Lisboa exótica e cosmopolita ${ }^{21}$. Os Jerónimos e a Torre de Belém tornam-se símbolos da grandeza do império e impõem um estilo arquitectónico que recebeu a designação de manuelino. A corte é animada nos seus serões pelo teatro de Gil Vicente - que a rainha D. Leonor, viúva de D. João II, protegia - pela poesia palaciana, pela música, em que D. Manuel era aficcionado e o jovem da corte Damião de Góis era perito ${ }^{22}$. Até aos moços negros do paço mandava o rei ensinar a Gramática.

Era esta a realidade em que se movia a consciência crítica e racional, o espírito empreendedor e magnificente de D. Diogo de Sousa. Encontrandose em Itália, na embaixada ao Papa de 1505, ao regressar a Portugal, faz a entrada solene na cidade de Braga, sede do seu arcebispado, em 22 de Novembro deste mesmo ano. Estas festas, na sua espectacularidade, na sua pompa, são, pelo seu simbolismo, uma expressiva afirmação do poder espiritual da Igreja de Roma - em tempos de Savonarola e de prenúncios da Reforma - e uma oportunidade única de o novo antístite se apresentar à arquidiocese e, sobretudo, de dimensionar o seu poder de Senhor e

${ }^{21}$ As fontes de riqueza, que sustentavam canais de consumo e não de investimento, o abandono da agricultura, a expulsão dos judeus e o seu massacre em Lisboa, em 1506, iriam contribuir a passos largos para a descapitalização interna, verificada nos reinados de D. João III - que teve de abandonar as praças de África -, e, de forma dramática, no reinado de D. Sebastião. O tratado De regis institutione et disciplina de D. Jerónimo Osório (1572) denuncia, de forma insistente, esta realidade, e.g. H. Osorii Opera omnia (ed. Roma de 1592) : I. 528. $20-530.30$.

${ }^{22}$ Conhecido é o apreço de Erasmo pela música de Damião de Góis e o deleite que ela lhe trouxe e à "familia erasmiana", nos anos em que o humanista luso foi seu hóspede em Lovaina. 
Arcebispo, como competia a um verdadeiro princeps do Renascimento, já que o arcebispado era simultaneamente um potentado político ${ }^{23}$.

Não faltariam ocasiões para manifestar, ao longo do seu ministério de Arcebispo, o maior respeito pelo seu monarca, sem contudo deixar que os interesses da coroa ou da nobreza pudessem prejudicar os da sua arquidiocese, ou interferir na cabal concretização dos projectos que para ela tinha ${ }^{24}$.

A manifestação exterior do poder, de origem divina, que percorre a época helenística e o Império Romano, e o Cristianismo assimila (S. Paulo, Rom. 13. 1), apesar da individuação das duas instituições, Igreja e Estado, era inerente à grandeza do munus dos governantes, quer do poder espiritual quer temporal ${ }^{25}$.

O tema paulino da Igreja como "corpo de Cristo" insiste na diferenciação funcional e na solidariedade orgânica, necessárias ao bom fun-

${ }^{23}$ A importância das festas, das entradas solenes, no Renascimento, à maneira dos triunfos romanos, reveste-se de um simbolismo político, social e também religioso. Entre nós, estavam ainda bem presentes, na memória de todos, a entrada da princesa Isabel, esposa do Príncipe Afonso, em Évora, e a de D. Maria, esposa de D. Manuel, em Santarém, nas quais Cataldo profere, ou simplesmente compõe - porque, no segundo caso, não chegou a ser proferida - a oratio laudatória. Sobre o significado destas entradas, vide Ana Maria Alves s. d.

${ }^{24}$ Cf., A. de Jesus Costa 1993: 85-97, os diversos documentos, expressivos da sua atitude esclarecida sobre os poderes jurisdicionais que tem e de que dispõe, com independência, na administração da Arquidiocese Primaz de Braga, e a ajuda material concedida a D. João III para a compra das Molucas, em 11 de Novembro de 1528 e 8 de Maio de 1529 (docs. 14 e 15); diplomática resposta negativa que deu, em 30 de Novembro de 1524, a este rei, que o queria transferir de Braga para Lisboa (doc.10, 70-75). Já antes, no reinado de D. Manuel, decorrente da política régia de concessão de forais, D. Diogo de Sousa entra em litígio com o Marquês de Vila Real, D. Fernando de Meneses, no tocante à jurisdição nas suas terras (Nair Soares 2009).

${ }^{25}$ Já no Quattrocento italiano, o conceito de "majestade", de "magnificência", no sentido moderno, aparece nas obras de humanistas como Platina, Pontano, Majo. Destes autores referimos, como exemplo significativo, os escritos de Giovanni Pontano, cujos títulos são por si elucidativos: De magnificentia, De splendore, De liberalitate, De beneficentia, entre outros. No seu De principe (ad Alphonsum Calabriae ducem) tece considerações sobre a maiestas - que se funda sobre a fama - e chega ao pormenor de especificar os trajos, os tecidos e suas cores, a forma de usar o cabelo, a palavra, o gesto adequado, a voz. 
cionamento da koinomia cristã ${ }^{26}$. A sua reinterpretação, no século VI, por Gregório Magno - não em termos de Corpo místico de Cristo e de difusão dos dons do Espírito dentro da Igreja, mas em sentido platónico, em termos de submissão do corpo à alma, ou da alma à razão, segundo o modelo de uma hierarquia natural (Platão, $R, 431 \mathrm{a} ; 590 \mathrm{c}-\mathrm{e}$ ) -, vai conferir uma maior amplitude e riqueza à imagética do poder, espiritual e temporal, ao longo da Idade Média e Renascimento. A ecclesia polimorfa de São Paulo, vista a esta luz, leva à elaboração de um simples modelo político, o do rector cristão que tem como tarefa de governo a cura animarum ${ }^{27}$. A aparente despolitização do termo rector, usado para designar os detentores do poder civil, corresponde, na realidade, à politização da função episcopal ${ }^{28}$.

Com efeito, a dimensão religiosa, cultural e política da figura e da acção de arcebispo bracarense vai reflectir a mundividência da época, que conciliava o peso da tradição com a modernidade. A entrada solene do Arcebispo, expressão externa do seu poder, patenteia a grandeza e a majestade do seu officium, do seu ministério - a magnificentia, o honor, a dignitas, a gloria ${ }^{29}$ - da sua potestas de antístite, e representa a afirmação da Igreja no governo espiritual e temporal dos povos. O conceito humanista de glória, associado à honra da função, permanece nos autores do século XVI ligado aos conceitos de dignitas, magnanimitas, magnificentia ${ }^{30}$. Mais

${ }^{26}$ O Corpo místico é identificado com a Igreja, a reunião dos crentes; Cristo é a cabeça dessa reunião; o Espírito Santo, a alma (Ef. 1, 22-23; Col. 1, 18.19.24; 2, 18-19; Ef. 4, 11-12.15-16)

${ }^{27} \mathrm{O}$ termo rector, de uso frequente no vocabulário jurídico imperial, passa a ser usado, a partir do século VI (a Regra pastoral de Gregório Magno é escrita em 591), como sinónimo de rex ou dominus, no lugar de pastor e sacerdos. Vide R. A. Markus 1991: 138-141; Michel 2006: 89-97.

${ }^{28}$ Michel Senellart (2006): 94-95: A Regra pastoral de Gregório Magno, redigida para os bispos, foi considerda desde Alcuíno, na época carolíngia, a época em que surgiram os Specula principum, como manual para uso dos reis. Na verdade, após a época constantino-teodosiana, em que havia colaboração entre a Igreja e o império (séc. IV), e ultrapassado o período das invasões bárbaras e o fim do império romano do Ocidente (século V), surgia, no final do século VI, uma época em que a Igreja cobrira o mundo, não havendo mais lugar, no seu seio, para uma autoridade secular.

${ }^{29}$ Estas são as virtudes colocadas nas quatro rodas do majestoso carro triunfal de Maximiliano I - em que Dürer representa qualquer príncipe cristão - sobre as quais o triunfo avança (Nair Soares 2004: 190 e sqq.).

${ }^{30}$ Nair Soares, 1994: 271-276. O termo magnanimitas é um neologismo 
ainda, magnanimitas e magnificentia tornam-se sinónimos. Não há dúvida de que no Humanismo em geral, e também entre nós, o conceito de magnanimitas corresponde ao aristotélico: é a magnanimitas uma espécie de ornamento das virtudes - porque está na origem delas - digno da maior honra, que é sempre a recompensa das próprias virtudes ${ }^{31}$. A virtude aristotélica da magnificentia (EN 1122a-1123a 30), que convida a dar todo o brilho possível, grandeza e prestígio às funções nobres e distinções $(E N$ 1122b 30), informa também o conceito renascentista de magnificentia. É nesta acepção que as festas, as entradas solenes, os cortejos de obediência ao Papa, à maneira dos triunfos romanos, com um carácter político, social e também religioso eram por demais familiares a D. Diogo de Sousa, que foi Deão da Capela Real, membro de duas embaixadas à cúria romana, e conselheiro de estado - como é designado na oração proferida ao papa Alexandre VI, em $1493^{32}$.

Caracterizar o êthos de D. Diogo de Sousa, à margem da sua função, não faria qualquer sentido: o ideal de "glória", de "magnificência", tão expressivo no Renascimento, é inerente ao Senhorio, ao Arcebispado de Braga e definidor da principis imago. Representante de Deus entre os homens, é na hierarquia eclesiástica, no exercício dos seus poderes, espi-

forjado por Cícero a partir de megalopsychia, virtude da moral estóica que engloba as virtudes andreia e karteria (cf. a divisão das virtudes, segundo Panécio, feita por Cícero, Part. 76-78). Contudo, o termo magnanimitas - usado pelo Arpinate uma única vez (Off. 1. 152), substituindo-o pelas expressões magnus animus, magnitudo animi - associado no latim cristão ao conceito de humilitas, vai ser repensado pela primeira vez, à luz dos princípios aristotélicos, por Santo Alberto Magno. Mas a conciliação entre estes dois conceitos, por assim dizer antagónicos, da filosofia antiga e da moral cristã, cabe a S. Tomás de Aquino que, em termos de espiritualidade medieval, faz a síntese do problema então debatido. R.-A. Gauthier, O. P. 1951: 158-169.

${ }^{31}$ Vide Aristóteles, EN, 1123 b 25 - 1124 a 5. Define-a já, nestes termos, Diogo Lopes Rebelo (1951: 96), no cap. VII do seu tratado dedicado ao rei D. Manuel, De republica gubernanda per regem (1496).

${ }^{32}$ Recorde-se a entrada do Marquês de Vila Real, D. Fernando de Meneses, nos seus domínios, em 1509, e a saudação, em oração latina, de Salvador Fernandes, impressa em Ferreirim, próximo de Lamego; e as entradas régias das princesas castelhanas D. Isabel - que veio casar com o Príncipe Afonso, filho de D. João II, e foi, já viúva, a primeira mulher de D. Manuel -, e D. Maria, segunda mulher de D. Manuel, cujas orações latinas de saudação, da autoria de Cataldo, chegaram até nós. 
ritual e temporal, tributário da honra, glória e louvor devidos ao Divino. Mais do que a glória pessoal é a dignidade que institucionalmente representa, com toda a sua carga simbólica, que o antístite bracarense se preocupa em enaltecer, em actos públicos, na riqueza de paramentos e utensílios litúrgicos, na magnificência artística das muitas igrejas e capelas que fez de novo, ou restaurou; no traço moderno que imprimiu à arquitectura da cidade, na estruturação do seu plano urbanístico, saneamento, salubridade. A ele se deve o Hospital de São Marcos, que ainda hoje se ergue na cidade, com a recente Faculdade de Medicina.

Numa palavra, a magnificentia de D. Diogo de Sousa, indispensável ao exercício do seu munus, como Arcebispo e Senhor da diocese primaz da Hispânia, manifesta-se na sua acção pastoral e jurisdicional e na "construção" da sua cidade, nas mais diversas expressões: religiosa, arquitectónica, intelectual, moral, social e económica. Torna-se, aliás, um aspecto marcante da sua personalidade a consciência do mérito da sua acção reformadora, do sucesso do seu trabalho árduo e contínuo, dispendendo bens pessoais para a concretização da sua obra, dirigida ao bem comum, sem guardar para si senão o indispensável, como tantas vezes repete ${ }^{33}$.

À maneira humanista, D. Diogo de Sousa quer ver elogiada, na língua de divulgação universal, o latim, a capital da sua arquidiocese, na nobreza e ancestralidade do seu património cultural de ascendência romana ${ }^{34}$. A consciência do valor das letras que tornam imortais os feitos dos homens, as suas obras dignas de louvor, como o Pro Archia ciceroniano recorda, aliado ao gosto do tempo pelas laudes ciuitatum, que Cataldo tinha

${ }^{33}$ Vide e. g. o Memorial (do que devia ser dito a D. Manuel), de 23 de Outubro de 1519: «todo o meu tempo e fazenda despendo em meu officio sem me lembrar senão o pão de cada dia, nem espero que per minha morte me achem heranças compradas, nem tizouros escondidos» (Avelino J. Costa 1993: 61); a carta de 24 de Março de 1528, dirigida a D. João III: «E ponha ante si quam poqua sustancia he Braga e que a fiz de novo e despendi nella tanto tempo e dinheiro e não pera ficar a meus herdeiros e como nunca procurei de ter no mundo hum soo palmo de terra, tudo o que fiz foi por Deos e pella alma de vosso pai que me deu este arcebispado e despois pella vossa e muito adiante pella minha» (Avelino J. Costa 1993: 85);

${ }^{34}$ As descobertas arqueológicas são colocadas na cidade, de forma a serem valorizadas pela sua exposição. 
inaugurado entre nós, inspiram e motivam D. Diogo de Sousa ${ }^{35}$. Escolhe o seu conterrâneo André de Resende - o poeta Resendius que, no dizer de Clenardo, se distingue entre os vates do seu tempo - para cantar, em verso, a cidade que adoptou como sua, que engrandeceu e prestigiou, e que guarda os seus restos mortais. Resende terá composto, cerca de 1526, um poema épico, hoje perdido, intitulado De Bracarensis urbis antiquitate et laudibus, a sua primeira composição poética, de que há notícia ${ }^{36}$.

Dom Rodrigo da Cunha refere-se a este poema, de que transcreve cinco versos da invocação, nestes termos ${ }^{37}$ :

«Não contente com assi ennobrecer a sua cidade [sc. Com igrejas e outros monumentos], buscou quem também com a pena, \& estylo, a fizesse famoza, dando noticia aos presentes, \& vindouros de sua primeira fundação. Foi este o grande fr. Angelo André de Resende [...]. Encomendoulhe o Arcebispo esta obra, \& elle, como quem o tinha por fautor, \& Mecenas de todas as boas letras, dentro em dez dias, lhe mandou hum Poema de maes de trezentos versos da fundação de Braga, tão polido, \& apurado, tão cheio de erudição, e outras elegancias, qual o podia fazer o melhor poeta dos que hoje veneramos.».

Admirável é a organização administrativa das jurisdições eclesiásticas de D. Diogo de Sousa, a par da sua acção pastoral, no quadro da sociedade portuguesa, na época decorrida de 1495-1505, enquanto foi Bispo do Porto, e de 1505-1532, quando já era Arcebispo e Senhor de Braga.

A arquidiocese de Braga, desde 1501, ano da morte do Arcebispo D. Jorge da Costa, até 1505, data em que D. Diogo de Sousa é nomeado

${ }^{35}$ Cataldo, com o "Elogio de Bolonha", abre curso, entre nós, ao elogio de cidades, muito frequente no século XVI: André de Resende, além de elogiar Lovaina e a sua Universidade, faz o elogio de Lisboa, no poema Vincentius Levita et Martyr e na Oratio de 1534, que transcreve um longo trecho deste poema épico; Damião de Góis, o amigo de Resende, elogia Lisboa, em Descriptio urbis Olysiponensis, e Inácio de Morais a cidade de Coimbra, em Encomium Conimbricae.

${ }^{36}$ A composição deste poema deve ter ocorrido cerca de 1526, numa altura em que André de Resende, de passagem por Portugal, se preparava para partir, pelos mares da Galiza, para os Países Baixos. André de Resende irá celebrar o nome da cidade em que ambos nasceram, em História da Antiguidade de Évora e De antiquitatibus Lusitaniae.

${ }^{37}$ José Marques (ed) 1989: 297-298 (cap. LXXI, §5). 
Arcebispo, esteve em situação de grande irregularidade ${ }^{38}$. Além disso, os costumes do clero e do povo em geral, sem instrução e sem cultura, apresentavam manchas deploráveis. A mancebia de eclesiásticos e leigos, solteiros e casados, era muito vulgar, a julgar pelas Constituições diocesanas de 1496 (Const. XV e XVI) que saíram do Concílio diocesano do Porto, de 24 de Agosto de 1496. Apesar das cominações que tanto as leis canónicas como as civis faziam contra a mancebia, as paixões sensuais sobretudo de membros do clero eram escandalosas, como documenta o teatro de Gil Vicente - designadamente o Auto da Barca do Inferno, a Comédia sobre a divisa da cidade de Coimbra e a Farsa de Inês Pereira - que não é pura ficção, pois os factos conhecidos corroboram largamente as sátiras do poeta $^{39}$.

D. Diogo de Sousa, de um tino administrativo e um bom senso inigualáveis, vai iniciar o desempenho do seu munus eclesial, em condições de notável fragilidade institucional. A grande extensão geográfica da arquidiocese e os vários domínios da vida da comunidade, a necessitarem de organização e intervenção, envolveram uma máquina burocrática e um número de funcionários consideráveis que D. Diogo de Sousa soube gerir e dirigir, como fautores de progresso e modernidade - sem ficar a dever nada a ninguém, favorecendo o mérito dos seus colaboradores com benefícios ${ }^{40}$.

${ }^{38}$ É que D. Jorge da Costa, pouco antes de morrer, renuncia ao Arcebispado e a todos os seus benefícios em favor do irmão, também chamado D. Jorge da Costa, cardeal de Alpedrinha. Intervindo D. Manuel neste caso, com a solução da nomeação de um coadjutor e futuro sucessor, dada a permanência do Cardeal na cúria romana e a sua idade avançada, os sucessivos embaixadores de El-rei consideraram a causa perdida: todos os negócios que interessavam ao cardeal de Alpedrinha, pela sua grande influência, eram por ele próprio despachados. Sem nunca sair de Roma, este Cardeal governou a prelazia principal do reino e, ao renunciar a ela em benefício de D. Diogo de Sousa, garantiu o bispado do Porto para seu sobrinho D. Diogo da Costa e para si a pensão anual de quatro mil cruzados. Vide Fortunato de Almeida 1968 (vol. II): 47-48; 597 sqq.

${ }^{39}$ Vide Fortunato de Almeida 1968 (vol. II): 489- 491 (cap. XIV).

${ }^{40}$ No Memorial endereçado a D. Manuel (em 23 de Outubro de 1519) contra a interferência nos coutos do arcebispado, D. Diogo de Sousa afirma: «Guoardo o que devo a todos e a ninguem tomo justiça nem fazenda, nem tem a que deva hum soo vintem e quanto ou quam pouco aproveito a todos com o meu elles o digão» (Avelino de J. Costa 1993: 62). 
Prelado e príncipe - com todos os direitos jurisdicionais, no cível e no crime, fiscais e legislativos -, D. Diogo de Sousa usa o seu poder com discernimento e fervor pastoral, o que define a excelência do seu governo.

Marco indelével da sua arte de governar, é o Sínodo diocesano de Braga de 1506. Nesta reunião, pediu o Arcebispo ao cabido e mais clero «um subsídio caritativo» para pagamento de seus encargos com a expedição das bulas do arcebispado, em que gastara oito mil e quinhentos cruzados, que tomara de empréstimo em bancos, quantia esta que era acrescida dos encargos cambiais, pelo que estava em dívida de doze mil cruzados; além disso, tinha as rendas do bispado oneradas com a pensão anual de quatro mil cruzados, imposta em favor do seu antecessor D. Jorge da Costa, cardeal de Alpedrinha. No mesmo sínodo, publicou Constituições para a sua diocese ${ }^{41}$.

O Sínodo diocesano bracarense retoma muitos dos príncípios enunciados nas Constituições do Sínodo do Porto e acrescenta outros, de acordo com a realidade da arquidiocese de Braga e sua especificidade, que constituem um verdadeiro programa pastoral pré-tridentino. Dirige-se este à reforma dos costumes, às práticas rituais e liturgia, com uma exigente preocupação catequética, mais didáctica e pedagógica na sua aplicação prática. Este Sínodo apresenta cinquenta e oito decisões coincidentes com os sessenta items estabelecidos no Sínodo do Porto.

"Senhor de Braga" - à maneira de um princeps do Renascimento -, entre as suas funções de carácter militar e judicial, herança do ministério régio medieval, acrescenta ainda outras, designadamente, as de carácter legislativo ${ }^{42}$.

$\mathrm{Na}$ verdade, por toda a Europa, à medida que as estruturas centralizadoras e administrativas da monarquia se consolidam, o poder legislativo dos "principes" aumenta de forma significativa. A realização concreta do princípio que faz do soberano depositário de todos os poderes e fontes do direito, que tem origem na profunda romanização jurídica da vida privada e pública europeia, leva à necessidade da recolha das leis para as tornar acessíveis aos súbditos ${ }^{43}$. Em Portugal, além das Ordenações régias, há todo um conjunto de leis decorrentes da função legislativa dos soberanos,

${ }^{41}$ Dom Rodrigo da Cunha 1989: 292-293.

${ }^{42}$ Vide e.g. Nair Soares 1994: 254-256.

${ }^{43}$ Vide Lester K. Born 1928: 504 («With the exception of some attention devoted to education, and some suggestions of economic development, the prince's functions are mainly divided between the military and the judicial»). 
que adquirem valor de direito positivo e são recolhidas, a pedido do rei, em colectâneas ou compilações ${ }^{44}$. Além disso, as Constituições das dioceses são direito subsidiário das Ordenações régias.

D. Diogo de Sousa, prelado culto e homem avisado, revela o sentido de opportunitas - num outro contexto ideológico, bem diverso do enaltecido por Maquiavel - próprio de um grande princeps renascentista, apostado na modernidade ${ }^{45}$ : acolhe com entusiasmo as inovações da técnica e edita, a 4 de Janeiro de 1497, nos prelos de Rodrigo Álvares, as Constituições, saídas do sínodo portuense do ano anterior. É este o primeiro livro impresso no Porto $^{46}$.

Reconhece o Arcebispo de Braga a importância da imprensa, cuja invenção Garcia de Resende saudará na sua Miscelânea (1516), nestes termos: «E viimos em nossos dias/ ha letra de forma achada/ com que a cada passada/ crescem tantas livrarias/ e ha sciencia he augmentada ${ }^{47} . \mathrm{Na}$ verdade, volvidos cerca de trinta anos sobre a descoberta do tipo metálico móvel, a arte da imprensa dá os seus frutos entre nós. Além de obras de devoção, ou ligadas à prática religiosa, ou à prevenção das doenças, as obras que mais frequentemente são editadas, nos finais do séc. XV, princípios do XVI, são relativas à arte de marear, gramáticas, e entre elas a de Pastrana, cartilhas de aprender a ler, catecismos, as Epistolae et orationes de Cataldo - saídas dos prelos de Valentim Fernandes, em Lisboa, a 21. 2. 1500 - e a oração de Salvador Fernandes, proferida na entrada de D. Fernando de Meneses em Vila Real, capital do seu marquesado, em 1509, impressa pelo «industrioso Teles», Antonio Tellez, de Toledo, em 1. 3. 1509, em Ferreirim, no limite da cidade de Lamego ${ }^{48}$. Esta última publicação

${ }^{44}$ Vide e.g. Nair N. C. Soares 1994: 254-256.

45 A Opportunitas é uma das rodas - ladeada de figura feminina que a representa - do Grande Carro Triunfal de Maximiliano I da autoria de Albert Dürer. Vide desenho preparatório e a simbologia da Imago principis christianni (in Nair Soares 1994: 191-198) e o modelo de Maquiavel (Ibidem, 198-298).

${ }^{46}$ Decorrido menos de um ano sobre a sua nomeação como Bispo do Porto (23 de Outubro de 1495), convoca um Sínodo para 24 de Agosto de 1496, que prepara as Constituições, por si editadas a 4 de Janeiro de 1497, nos prelos de Rodrigo Álvares (Vide José Barbosa Machado 2006).

${ }^{47}$ E. Verdelho (ed.) 1994: 570 (Miscellanea, est. 179).

${ }^{48}$ Artur Anselmo 1981: 289-332. O livro português mais antigo, impresso em Portugal, é o Tratado de Confissom, editado em Chaves, em 1489, e descoberto em 1965 pelo Prof J. V. de Pina Martins (Pina Martins 1989: 767-976). 
revela o significado simbólico que as entradas de principes - o mesmo será dizer, de nobres ou figuras de destaque na hierarquia social, civil ou eclesiástica - adquiriam na imagética renascentista e na ideologia do poder.

Consciente da importância do livro impresso na formação intelectual, moral e religiosa dos seus diocesanos, D. Diogo de Sousa procede de forma a que se tornem seus fiéis colaboradores Rodrigo Álvares, tipógrafo e editor-livreiro, e Juan de Porres, editor salmantino.

Apesar de a produção editorial ser escassa e de privilegiar o livro devoto e litúrgico, o empenho do Arcebispo bracarense, neste particular, é um forte indicador de um espírito de vanguarda, no período seminal do Humanismo, entre nós ${ }^{49}$.

Conhecidas são as publicações que levou a cabo: o Breuiarium Bracarense, nas suas três edições (1511,1512 e 1528), o Missale Bracarense (1512), o Manual Bracarense (1517) e a Arte de rezar as horas canonicas ordenadas segundo as regras e costume bracarense, da autoria do Pe. Xisto Figueira, que sai a lume em Salamanca, em 1521.

Numa altura em que os monarcas portugueses se empenham na reforma diocesana do clero e no melhoramento das práticas catequéticas junto dos diocesanos - à semelhança do que acontecia na Europa, à sombra da Universidade de Paris, designadamente, onde avultam figuras, como Lefèvre d'Étaples e seu discípulo Josse Clichtove com sua obra notável, conhecida e divulgada em Portugal ${ }^{50}$-, a personalidade humana e intelectual

${ }^{49}$ A ligação do primeiro humanismo à imprensa, entre nós, é prova irrefutável do reconhecimento do papel das humaniores litterae na formação integral do homem e do amor que lhe dedicam os seus cultores e mecenas. Lembro, entre eles, D. Jorge, o discípulo de Cataldo que, em 1499, concedia protecção a Martim Vaz, primeiro livreiro de que há notícia; ou D. Pedro de Meneses, conde de Alcoutim; e a rainha velha, D. Leonor, viúva de D. João II, a quem a arte tipográfica muito deve: a expensas suas, sai dos prelos de Valentim Fernandes a edição da Vita Christi (1495). Nos mesmos prelos, se publicam a 21 de Fevereiro de 1500, as Epistolae et orationes de Cataldo Parísio Sículo.

${ }^{50}$ A obra de Lefevre d'Étaples Quintuplex Psalterium (1509) - em que «primeiro terçou armas pela renovação dos estudos sagrados, advertindo não só a urgência de se fazer da Escritura a base da teologia e da piedade dos fiéis, mas também a necessidade de assentar a sua exegese nos cânones científicos do Humanismo» - foi recebida pelo Cardeal Cisneros no próprio ano da sua publicação, por intermédio de Charles de Bovelles. Cf. Silva Dias 1960: 495497. O Cardeal Cisneros, fundador do Colégio Trilingue de Alcalá de Henares, serviu de referência a D. Diogo de Sousa, não só no que se refere ao seu projecto 
de D. Diogo de Sousa, com uma formação superior em Direito Canónico e em Teologia, pesaram, por certo, na sua nomeação para altos cargos da hierarquia da Igreja, a que é inerente o ministério apostólico, fundamental na orientação, formação e educação do povo ${ }^{51}$.

Acontecimentos marcantes, como a reforma protestante e as guerras de religião na Europa, as lutas entre príncipes cristãos e a política de neutralidade de D. João III, sem esquecer a ameaça do perigo otomano e o alicerçar dos laços ibéricos - através do casamento de D. João III com D. Catarina, irmã de Carlos V, e deste imperador com D. Isabel, irmã do monarca português - dão-nos a medida da sabedoria do antístite bracarense na resolução dos problemas do seu tempo, e da sua acção exemplar e comprometida, na resposta às solicitações do monarca.

E não foram elas de somenos importância, se lembramos a ajuda prestada para a compra das Molucas e para o casamento de D. Isabel com o Imperador. Em todas as grandes empresas a que este rei deitava mãos, recorria ao auxílio e à magnanimidade do Arcebispo, mesmo quando a delicadeza das situações se deveria impor. Refira-se, neste sentido, o pedido de auxílio para a concessão de sessenta bolsas, no Colégio de Santa Bárbara em Paris, quando o D. Diogo de Sousa acalentava o sonho, desde o tempo

educativo, bem como à magnificente obra na sua cidade.

Josse Clichtove - cuja influência se exerce em Portugal, conservando-se várias das suas obras nas bibliotecas portuguesas (Nair Soares 1994: 137-138) - discípulo da Universidade de Paris e de J. Lefèvbre d'Étaples, soube contudo afastar-se do designado "febrismo" e mesmo de certas posições de Erasmo, relativamente ao monaquismo; reflecte nas suas obras, de forma brilhante, dentro da mais estrita ortodoxia, sobre a reforma do clero, o ideal de episcopus, a liturgia e o cerimonial litúrgico, numa atitude muito próxima da que informará os textos tridentinos, cujos ideais muito antes experienciou. É autor de um De perfecto episcopo e de um Antilutherus, entre outras obras, ligadas à espiritualidade sacerdotal e ao ritual litúrgico, na sua essencialidade - simbólico da dignidade e glória de Deus e memorial da Sua presença, entre os homens - que revelam no seu conjunto a efervescência de ideias e toda a mundividência de uma época de debate religioso que D. Diogo de Sousa também viveu, desde os anos em que frequentou a Universidade de Paris, quase coincidentes com os de Josse Clichtove. (J. P.Massaut 1968: 118-175).

${ }^{51}$ Sobre a crise religiosa do séc ulo XV, a reforma da vida diocesana e das ordens religiosas - da vida monástica e das ordens activas - ao longo do século XVI, em Portugal, ao tempo de D. Diogo de Sousa, vide Silva Dias 1960: 33-177; Battaillon 1974. 
do rei, seu pai, de instituir estudos superiores de qualidade, em Braga, no Colégio de S. Paulo que fundara e construíra ${ }^{52}$.

$\mathrm{O}$ ensino em Portugal, desde a primeira metade do século XV, época áurea do humanismo italiano, apresenta-se por demais carenciado em relação à Europa. Já então os príncipes de Avis e o seu círculo de letrados revelam preocupações cívicas e pedagógicas próprias do seu proto-humanismo. A corte torna-se o grande centro cultural, incentivando a criação literária e a prática da leitura: traduzem-se os clássicos latinos, formam-se as primeiras bibliotecas, como as de D. Fernando e de D. Duarte ${ }^{53}$. Vasco Fernandes de Lucena, um dos tradutores mais activos dos autores clássicos "em linguagem", ao serviço dos ideais educativos dos príncipes de Avis, encontrava-se ainda ao serviço da corte, no tempo de Cataldo e de D. Diogo de Sousa ${ }^{54}$.

Já no Livro da Virtuosa benfeitoria, obra escrita dentro da concepção ética dos "deveres do senhoryo", em data incerta, mas muito provavelmente entre 1429 e 1431 - após as enriquecedoras viagens do Infante das Sete partidas $^{55}$ - e ainda na famosa carta de Bruges, escrita durante essas viagens e dirigida entre 1424 e 1428 ao futuro rei D. Duarte, tece o Infante D. Pedro considerações de singular interesse sobre uma reforma estrutural profunda do ensino, conforme o modelo dos Colégios de Paris e Oxford, que então visitara. Em seu entender, não só o clero possuiria uma instrução mais sólida, benéfica ao desempenho do seu munus, como ainda se corrigiria o povo, cresceriam os letrados e as ciências, o que seria muito proveitoso à administração régia ${ }^{56}$.

${ }^{52}$ Vide Avelino de J Costa 1993: $76-89$ (docs. 11, 12, 13; 14; 15).

${ }^{53} \mathrm{O}$ filho de D. Duarte, D. Afonso V, educado pelos italianos Estêvão de Nápoles e Mateus de Pisano, e muito louvado pela sua cultura intelectual, organiza, no Paço da Alcáçova, em Lisboa, o núcleo da futura Livraria Real, que abre, pela primeira vez, as portas ao público.

${ }^{54}$ Figura de prestígio da primeira metade do século XV, cuja actividade político-literária se prolongou até quase ao fim do século, Vasco Fernandes de Lucena foi embaixador de D. Duarte ao concílio de Basileia e ao papa Eugénio IV e de D. João II ao papa Inocêncio VII.

${ }^{55}$ Vide Arnaut 1993: 173-217.

${ }^{56}$ É notável a modernidade do seu pensamento pedagógico, antropológico e sócio-político, expresso embora numa lógica discursiva, própria das quaestiones medievais, sem que a sua prosa deixe de ser semeada de expressões de um colorido e de uma graça imagética surpreendentes (Nair Soares 1993: 289-314). 
D. Diogo de Sousa, cerca de três quartos de século mais tarde, poderia subscrever, no espírito e na letra, estas asserções do Infante D. Pedro e darlhes apenas um outro desenvolvimento, mais consentâneo com a época do Humanismo.

No último quartel do século XV, por altura da chegada a Portugal de Cataldo Parísio Sículo - pedagogo e secretário latino, orator regius, durante os reinados de D. João II e D. Manuel e considerado o introdutor do Humanismo, entre nós - a Universidade portuguesa não granjeara prestígio europeu. Mantivera, desde a fundação de D. Dinis, a mesma estrutura e o mesmo plano de estudos até à reforma do Infante D. Henrique (1431) e, tendo embora beneficiado da protecção do Infante D. Pedro, de D. Afonso V e de D. João II, no sentido da sua modernização, não atraíra a elite portuguesa. Os nobres, sobretudo, mandavam educar os filhos fora do reino, o que levou os procuradores do povo a pedirem a $\mathrm{D}$. Afonso $\mathrm{V}$, nas cortes de 1473, e a D. João II, nas de 12 de Novembro de 1481, que se limitassem as tenças e pensões régias concedidas aos estudantes.

A política educativa de D. Manuel enquadra-se num vasto plano: além dos estatutos novos conferidos à Universidade, em 1508, manifesta o monarca, nesta mesma data, a intenção de criar um Colégio em Lisboa, e concede aos «emprimidores de liuros», «graças priuilegios liberdades e honras que ham e deuem aver os caualeiros de nossa casa ${ }^{57}$. Se até então o ensino se concentrava fundamentalmente em duas cidades - Lisboa, com a Universidade, e Coimbra, com o Mosteiro de Santa Cruz -, num esforço concertado entre a coroa e a Igreja, D. Manuel tenta suprir as carências a que ficava sujeita a população do norte e sul do país. Leva, então, a efeito um projecto de instituir Colégios em Braga, Guimarães e Évora.

Em 1509, o Arcebispo de Braga, D. Diogo de Sousa cria nesta cidade o Colégio de S. Paulo, com o apoio de D. Manuel, que só vemos a funcionar cerca de $1532^{58}$. A primeira obra que quis fazer em Braga, afirma repetidamente o Arcebispo, foi um Colégio. E muitos são os documentos que provam o empenho que punha, nesta empresa ${ }^{59}$.

${ }^{57}$ Cf. Carta de 20 de fevereiro, ANTT, Chancelaria de D. Manuel, livro 5, fl. 6v. - Apêndice Documental, $n^{\circ}$ XIII.

${ }^{58}$ Sobre a sua orgânica e plano de estudos, vide Avelino de Jesus Costa 1961: 477-533. O Colégio de Guimarães viria a ser criado em 1512. Em 1517, o Colégio de S. Tomás, no Mosteiro de S. Domingos em Lisboa, e, em 1520, um Colégio em Évora.

${ }^{59}$ Vide e. g. Avelino de Jesus Costa 1993: 17-119. 
D. Diogo de Sousa, ao fundar o Colégio de S. Paulo e ao estabelecer na sua ratio studiorum as disciplinas da Gramática, Lógica, Teologia e Artes - saberes que abarcariam a formação integral de cidadãos e de clérigos - não poderia, apesar das designações tradicionais de cariz medieval, retroceder em relação aos métodos humanísticos que experimentara na sua formação, nem de regredir relativamente ao ensino ministrado por Cataldo, na corte. Corte esta que, no reinado de D. Manuel, se viria a transformar numa verdadeira academia de que beneficiaram humanistas como João de Barros e Damião de Góis ${ }^{60}$.

${ }^{60}$ D. Diogo de Sousa além de frequentar, na corte, as aulas de Retórica de Cataldo Parísio Sículo e de conhecer e apreciar a educação moderna europeia, teve como modelo, capaz de imitar na sua cidade, o Colégio Trilingue de Alcalá de Henares, fundado por um eclesiástico, o Cardeal Ximénez de Cisneros, a quem se deve a publicação da Bíblia Poliglota. Esta figura, do outro lado dos Pirineus - tal como D. Diogo de Sousa em Portugal -, participou durante toda a sua vida, em maior ou menor medida, em tudo o que se fez no reinado dos Reis Católicos e contribuiu decisivamente para a configuração do novo estado espanhol, ao reformar a vida religiosa, que tinha caído em grande relaxamento moral, e ao compreender que toda a renovação da sociedade começava pela educação. Sem ser propriamente um erudito, fundou no ano de 1499, a partir do antigo Studium Generale de Alcalá de Henares, do qual Cisneros fora aluno, uma das instituições mais influentes na cultura espanhola e uma das Universidades mais importantes da Europa. O Cardeal Cisneros, consciente da importância desta sua fundação, não economizou esforços para tornar arquitectonicamente o seu Colégio-Universidade um marco urbanístico adequado e paradigmático, concedeu-lhe um financiamento generoso e recrutou os melhores mestres da época. A colocação da primeira pedra do edifício que abrigaria esta instituição ocorreu a 14 de Março de 1501; em 1508 começaram as aulas e em 1510 dotou a sua fundação de Constituições.

A coincidência epocal, dos ideais e da acção dos dois eclesiásticos ibéricos não deixa de ser reveladora. Também a cidade de Alcalá de Henares - como a Braga de D. Diogo de Sousa - se viu imensamente beneficiada por este Cardeal. Responsável pela construção da Santa Casa de Caridade de Illescas, foi ele próprio que dirigiu as obras; substituiu o templo já deteriorado de São Justo por um belo edifício gótico, para o qual conseguiu o título de Magistral - a Igreja Magistral de Alcalá de Henares, hoje Catedral Magistral, situada em pleno coração da cidade, onde repousam os seus restos mortais. Mais ampla e profunda seria, neste particular a acção do Arcebispo bracarense. Apenas a sua obra educativa, o Colégio de Sâo Paulo, não pôde equiparar-se ao Colégio Trilingue de Alcalá de Henares. 
Aliás a pedagogia de D. Diogo de Sousa, no sentido estrito do termo, não pode ser apreciada apenas pela enumeração que faz dos saberes ${ }^{61}$. $\mathrm{O}$ ensino da Gramática - e sabemo-lo por Cataldo e pelos tratados de gramática como o de Estêvão Cavaleiro, que sai a lume em 1516 - integrava a Retórica e a Poesia e deveria fazer-se, como recomendava Quintiliano, a partir da leitura e interpretação dos textos clássicos, no original. E não faltaram, entre nós, manuais de "Arte nova" de gramáticos de formação europeia, a que as Elegantiae linguae latinae de Lorenzo Valla deram o tom. A disciplina de Lógica também não corresponderá senão no nome aos conteúdos tradicionais. Aliás, a Lógica como a arte de bem discorrer e de bem dispor os argumentos é essencial a todo o processo educativo e um dos objectivos primordiais da formação integral do homem renascentista.

Diferentes correntes filosóficas se difundem a partir do Quattrocento, com incidência directa na argumentação discursiva, em que se afirma o ideal retórico da latinitas, no sentido da valorização da palavra. Além do aristotelismo e do platonismo, a partir sobretudo das traduções latinas de Leonardo Bruni e Marsilio Ficino, impõe-se o estoicismo, desde Petrarca, com a influência de Séneca e a tradução do Manual de Epicteto, feita por Poliziano. Se os neo-aristotélicos, como António de Gouveia, valorizam o papel da Lógica e dos silogismos, há os que defendem o "método" na argumentação, inspirados em Platão, designadamente na discussão da diaeresis, no Fedro (265e) e no Sofista (218b), como acontecerá com Pierre de la Ramée, que se opõe em acesa polémica ao jurista português, António de Gouveia, o famoso mestre de Cujas. O silogismo, apoiado em exempla, fornecia assim aos neo-aristotélicos uma contrapartida aos "lugares comuns" defendidos pelos neoplatónicos. O neo-estoicismo, por seu lado, manifestava uma acentuada preferência pelo estilo sentencioso de cariz

${ }^{61}$ Vide Amadeu Torres 2006: 35-44 - reeditado, com diferentes títulos, nas revistas Humanidades 2006: 493-503 e Humanitas 58 (2006) 291-301. Neste estudo, o autor acentua o pendor tradicional, escolástico, da formação de D. Diogo de Sousa, com reflexos no seu projecto educativo. Quanto a nós, a concretização do seu sonho, a criação na cidade de Braga de um Colégio de ensino superior de qualidade, dentro dos padrões da educação moderna - D. Diogo de Sousa apontou a D. João III, entre outros, o modelo do Colégio Trilingue de Alcalá - falhou, por falta de apoios dos monarcas que seguiram outras estratégias de política cultural, contentando-se o antístite, sem desistir dos seus propósitos, com o mínimo que lhe foi possível realizar, na sua cidade. 
moralizante, que os Progymnasmata da Segunda Sofística, adoptados pela pedagogia humanista moderna, divulgaram.

O estudo da Lógica não seria, por certo, um impedimento à modernidade da ratio studiorum proposta por D. Diogo de Sousa para o Colégio de S. Paulo, já que esse estudo se prolongou e recebeu novo incremento, no período áureo do ensino em Portugal, o que se seguiu à década de trinta do século $\mathrm{XVI}^{62}$.

Assim acontecia com todos os saberes no Renascimento, que o Panepistemon de Ângelo Poliziano enuncia, e que extravasavam em muito as disciplinas do trivium e do quadrivium. Apesar de estas, com conteúdos bem diversos, devido ao progresso dos conhecimentos e às novas perspectivas em que são encaradas, conservarem o mesmo nome, desde a Idade Média.

A estrutura curricular do Colégio de S. Paulo proposta por D. Diogo de Sousa, discípulo de Cataldo - representante do humanismo filológico e literário do Quattrocento italiano, em Portugal - não se distancia muito do pensamento pedagógico de André de Resende, na oração que profere na Universidade de Lisboa, em 1534, dois anos após a morte de D. Diogo de Sousa. Neste discurso, o discípulo de Erasmo em Lovaina dá a primazia à Teologia, ao enunciar as disciplinas, as humaniores litterae de que encarece o valor. Nos próprios sermões que Resende profere ou compõe por ocasião dos Sínodos de Évora, a lição do humanista impõe-se em vários domínios do comportamento humano, num discurso apelativo à missão da Igreja e ao papel essencial dos seus superiores hierárquicos, na formação e condução do povo de Deus, numa atitude similar à de Josse Clichtove e D. Diogo de Sousa e, anos mais tarde, de S. Carlos Borromeo e Frei Bartolomeu dos Mártires ${ }^{63}$.

${ }^{62}$ Em Portugal, no Colégio das Artes, como no Colégio da Guiena, em Bordéus, vai adoptar-se o manual Praeceptiones dialecticae (Paris, F. Morel, 1557) do aristotélico Nicolas de Grouchy - um dos bordaleses, professor de Montaigne, que vem para Coimbra com André de Gouveia e é o tradutor para francês da História do descobrimento e conquista da Índia pelos Portugueses de Fernão Lopes de Castanheda. Este manual de Grouchy, único usado no Colégio de Bordéus, é uma sequência de silogismos que ilustram virtudes morais, com exempla retirados da Ética a Nicómaco, o mais platónico dos livros aristotélicos. Em Coimbra, para servir de apoio aos seus cursos, Grouchy traduz um dos dois livros do Organon, que Aristóteles dedica ao silogismo, os Segundos Analíticos, conhecido na época por Aristotelis de demonstratione (Paris, M. Vascosan, 1554).

${ }^{63}$ Sobre Josse Clichtove, autor de uma obra Antilutherus e a sua atitude 
Apesar de distantes, no espaço e no tempo, se exceptuarmos a maior profundidade do saber filológico nas letras gregas e latinas e a atitude estética conciliada com o sentimento cristão, de inspiração erasmiana, as orações de Resende, proferidas nas academias de Lisboa (1534) e Coimbra (1551) e mesmo os seus Sermões de carácter moral e religioso, verdadeiros documentos das preocupações intelectuais e espirituais da época em que foram proferidos, evidenciam uma continuidade de ideais humanistas e eclesiais, desde D. Diogo de Sousa, sendo mesmo possível identificar semelhanças entre os dois humanistas, no que toca ao fervor pedagógico e à sólida preparação teológica, na singularidade do seu pensamento e zelo educativo.

Aliás, na oratória académica, desde a oração de Cataldo, pronunciada em Bolonha, em 1500 - que serviu de guião às que se proferiram, desde o início do século XVI, na Universidade, em Lisboa e Coimbra, no Colégio das Artes e nos Colégios dos Jesuítas -, permanece inalterado o modelo ciceroniano, em que o elogio das letras segue o Pro Archia; o ideal, que se propõe, do homem culto, virtuoso, perito na arte de bem falar, é dado pelas recém-encontradas obras retóricas de Cícero, Brutus, De oratore e Orator, e pela Institutio oratoria de Quintiliano. O programa de estudos, que estas orações preconizavam, era praticamente o mesmo, desde a oração de Cataldo ou a oração que D. Pedro de Meneses, pronunciada em 1504. As disciplinas apresentadas seguem a divisão aristotélica das ciências, que se agrupam no trivium ou artes sermocinales e no quadrivium ou artes reales, adoptando cada uma das orações uma determinada hierarquia de valores, em que é perceptível a evolução e o alargamento dos saberes, verificados no magistério universitário, ou mesmo no ensino de príncipes na corte.

Dirá, com razão, Joaquim de Carvalho que no Renascimento «a designação das disciplinas só tinha de medieval o nome, porque a matéria e a didáctica com que foram ensinadas já se apresentam com o selo da modernidade» ${ }^{64}$. É difícil assim depreender com objectividade, através da simples enunciação de uma ratio studiorum e suas disciplinas, os respectivos

pioneira no que toca à reflexão sobre a necessidade de reformar a Igreja dentro dos princípios da ortodoxia, vide J.-P. Massaut 1968.

${ }^{64}$ Joaquim de Carvalho 1950: 1-13. Segundo a ordem que se tornou tradicional desde Alcuíno, o trivium era constituído pela Gramática (isto é, o estudo do Latim, que se alargou ao Grego e ao Hebraico e incluía a Poesia), a Dialéctica e a Retórica. O quadrivium era constituído pela Aritmética, a Geometria, a Astronomia e a Música (consistindo esta última na aprendizagem do cantochão e respectiva teoria). 
conteúdos, a menos que sejam conhecidos, de alguma forma, os ideais educativos e culturais do seu autor, a sua formação individual e a forma mentis da sua época.

Foi D. Diogo de Sousa um discípulo da Universidade de Paris, mater studiorum, com a originalidade do seu humanismo, que aliava à eloquência a meditação da Escritura, na linha de São Bernardo de Claraval e de Jean Gerson, e reconhecia o primado da Teologia. Esta, mesmo incluindo a teologia teórica, nunca deveria ser abstracta, mas persuasiva e comovente, graças ao contacto com a Escritura, com os Padres da Igreja e com a eloquência latina. Eloquência esta que deveria ser utilizada em proveito da Teologia e da piedade, como antes de Gerson o fez Santo Agostinho, e o teorizou no livro IV do seu De doctrina christiana, inspirador da retórica de Erasmo.

Assim se identificava, na sua especificidade, o humanismo francês que iria impor o modus parisiensis, usado nos colégios universitários de França, em que se integra o Colégio de Santa Bárbara, dirigido por Diogo de Gouveia Sénior, frequentado por um escol de portugueses, e espanhóis, como Inácio de Loiola, o fundador da Companhia de Jesus. Este modus parisiensis, embora tivesse herdado elementos da pedagogia da Escolas dos Irmãos da Vida Comum, de finais dos século XIV e princípios do século $\mathrm{XV}$, é filho dos métodos da Escolástica, da sua forma de ordenar, dividir, distinguir, analisar, sistematizar e avançar de forma gradual e progressiva ${ }^{65}$. Foi este o método que D. Diogo de Sousa conheceu na sua formação parisina $^{66}$.

Os Estatutos de D. Manuel para a Universidade de Lisboa, as orações académicas e as obras de gramaticografia, desde finais de Quatrocentos, que podem considerar-se escritos de âmbito pedagógico, no sentido mais estrito da palavra, a juntar às cartas programáticas que D. Diogo de Sousa escreveu aos reis D. Manuel e D. João III, ao longo do seu governo da arquidiocese de Braga - reveladoras da sua cultura e do seu gosto de modernidade -, são meios privilegiados para se poder compreender o

${ }^{65}$ Gabriel Codina Mir 1968: 99-190; J. Manuel Martins Lopes 2002: 7890. Dirá Santo Inácio de Loiola: «As Artes ou as ciências naturais dispõem os espíritos para a Teologia, e servem para se ter dela perfeito conhecimento e prática, ao mesmo tempo que são, já por si próprias, auxílio para os mesmos fins» (Ibidem: 97)

${ }^{66}$ Cf. J.-P. Massaut 1968: maxime 123 sqq. 
alcance da ratio studiorum, elaborada por D. Diogo de Sousa para o Colégio de S. Paulo.

D. Diogo de Sousa, uma das figuras de maior prestígio, no reinado de D. João III - que o queria ter por conselheiro prudente e experimentado ${ }^{67}$ - não desiste do seu projecto educativo, denuncia, com grande objectividade, as carências existentes e apresenta as soluções para as resolver, com um realismo e um desassombro notáveis ${ }^{68}$.

O projecto cultural que D. Diogo de Sousa tem para a "construção da cidade" é apresentado em carta que envia de Braga a D. João III, em 21 de Setembro de 1527, alguns meses após o saque de Roma, ocorrido a 6 de Maio, e a morte de cento e quarenta e sete homens da guarda suíça que protegia o Papa Clemente VII. Neste mesmo ano de 1527, em que D. Diogo de Sousa apelava ao apoio do rei para a sua cidade, é levada a cabo a reforma do ensino em Santa Cruz de Coimbra, por ordem de D. João III, sob a direcção de D. Frei Brás de Braga, que estudara em Paris e Lovaina e era conhecido pela sua grande abertura às correntes da espiritualidade $\mathrm{e}$ da pedagogia erasmianas ${ }^{69}$.

Esta carta do Arcebispo a D. João III pode considerar-se um verdadeiro manifesto de uma política educativa nacional, que afina pelo diapasão da moderna pedagogia da Europa ${ }^{70}$. A forma directa e esclarecida como alerta o rei para o problema da falta de um projecto educativo que torne o Portugal das Descobertas um centro cultural europeu, ao nível da França, da Itália, da Espanha, sem ter necessidade de enviar os seus estudantes mendigar saber, fora de portas, é por demais expressiva. A vizinha Espanha - com a sua Salamanca, onde estudara Cânones -, onde existem muitos colégios universitários, criados com a ajuda da Igreja, e sobretudo o Colégio Trilingue de Alcalá, obra do cardeal Ximénez Cisneros, merecem a admiração do Arcebispado bracarense e servem de exemplo a seguir, entre nós ${ }^{71}$. Singular é mesmo a forma como D. Diogo de Sousa interpela D. João III, fazendo depender da cultura e educação do povo a sua "magnificência" de

${ }^{67}$ Vide a sua transcrição e fac-símile desta carta, in Avelino de Jesus Costa 1993: 76-81 (doc. 11).

${ }^{68}$ Ibidem.

${ }^{69}$ Cf. e.g. J. V. de Pina Martins 1989: 433, 436 e 566.

${ }^{70}$ Vide a sua transcrição e fac-símile desta carta, in A. de Jesus Costa 1993: 76-81 (doc. 11).

${ }^{71}$ Ibidem. 
governante de um vasto império, edificado por obra dos reis, seus antecessores, e de seus súbditos ${ }^{72}$ :

Esta somana me deu mestre Margalho duas cartas de Vosa Alteza, hũa de cremça pera ele. outra sobre os estudantes que quer mandar a Paris apremder Theologia, na quall m'emcomenda e manda que queira dar alguã soma de dinheiro prera alguns dos ditos estudamtes lá poderem estar [...].

«Olhe Vosa Alteza bem o acrecemtamemto que vosa coroa e reino recebeo de muy pouquos annos a esta parte e que ganhastes novos reinos e senhorios pera vós e destes maneira que outros rex christãos ganhasem outros de novo, que numqua forom sabidos nem conhecidos senam por muito trabalho dos rex vosos amtecesores e morte de seus criados e vasalos naturaes.

E pois vos Deus fez tamanho nam vos façaes vós, Senhor, menos do que vos Ele tem feito».

E prossegue D. Diogo de Sousa, o antigo estudante da Universidade de Paris, nesta sua carta dirigida ao rei, em resposta à que lhe enviara por mestre Margalho, a pedir «alguma soma de dinheiro» para a concessão de sessenta bolsas «para estudamtes que quer mamdar a Paris apremder Theologia» ${ }^{73}$ :

E nam cures de mandar a Paris sesemta escolares a apremder Theologia, mas manday vir de lá sesemta lemtes ( a modo de falar, porque até dez abastariam pera tudo) e emtam fazei hum colegio muy comprido e muy grande e de pouquas pimturas e lavores omde se leya Theologia e todalas artes e ciemcias que pera ela sam necesarias. E faça se em $1[0]$ guar comveniemte pera iso, o quall me a mim parece que será esta cidade de Bragaa ou o Porto pela calidade, ares e temprança da terra».

Este mesmo desejo de os estudantes portugueses não necessitarem de ir frequentar as universidades estrangeiras, será formulado pelo amigo de D. Diogo de Sousa, André de Resende, na oração proferida em 1534, na Universidade de Lisboa ${ }^{74}$.

${ }^{72}$ Ibidem.

${ }^{73}$ Ibidem. Em França, têm a preferência o colégio parisiense de Santa Bábara, dirigido por Diogo de Gouveia, o Velho, onde o rei D. João III institui cinquenta bolsas para estudantes portugueses, a funcionar desde 1529.

${ }^{74}$ Vide e. g. a oração proferida por André de Resende em 1534 que refere a 
D. João III, dez anos decorridos sobre a data da carta que lhe dirigira D. Diogo de Sousa, dará realidade ao projecto educativo nacional; procederá então a uma reforma cultural, por assim dizer sistemática, que corresponde ao generalizado entusiasmo europeu pelas Humanidades.

E nem Braga, nem o Porto foram as cidades escolhidas. O monarca português terá provavelmente seguido a orientação do humanista valenciano Luís Vives, na escolha da cidade universitária que viria a ser o grande centro intelectual, a cidadela do saber no quinhentismo português, Coimbra $^{75}$. Pela sua obra na cidade do Mondego, João Rodrigues Sá de Meneses, uma das figuras mais representativas do primeiro humanismo entre nós, no final do seu de Platano (1537), saúda o rei e formula o voto - o mesmo que D. Diogo de Sousa formulara, de forma tão empenhada, na carta de 1527 - de que as letras venham a inundar Portugal, para que «os portugueses não precisem de mendigar ciência e letras pelas encruzilhadas da Itália e de Castela, para vergonha sua, como outrora ${ }^{76}$.

urgência de elevar, em Portugal, as Letras acima das riquezas, dos títulos nobiliárquicos e da glória das armas (L. Andreae Resendii Lusitani Oratio pro rostris pronunciata in Olisiponensi Academia Calendis Octobribus MDXXXIIII). Vide ed. moderna, in André de Resende 1956: 32.

${ }^{75}$ A transferência definitiva da Universidade portuguesa para Coimbra, em 1537, e a fundação do Colégio das Artes em 1548 irão ser a expressão acabada da política cultural de D. João III. É muito provável que D. João III tenha seguido a orientação do humanista valenciano Luís Vives que, na carta que introduz o De tradendis disciplinis, dedicado ao monarca português, o incentiva a dar realidade a este projecto educativo na escolha da cidade universitária que viria a ser o grande centro intelectual, a cidadela do saber no quinhentismo português, Coimbra. Em seu entender, a cidade deveria ter um clima saudável (coelum ut sit salubre) e geograficamente situar-se, nem numa cidade demasiado concorrida, nem numa povoação limítrofe (nec publico itinere adjaceat...non in regionis limitibus). Cf. Joannis Ludovici Vivis Valentini Opera omnia, distributa et ordinata a Gregorio Majansio, tomus VI, De tradendis disciplinis: 2-4.

${ }^{76}$ João Rodrigues de Sá de Meneses - poeta do Cancioneiro Geral, tradutor de Ovídio, que merece rasgados elogios de Cataldo, que se lhe refere na qualidade de genro de D. Martinho Castelo Branco, dedicatário de uma obra do Sículo -, no final do diálogo De platano ( 1537), dá notícia de grande número de estudantes frente ao mosteiro de Santa Cruz, em Coimbra, onde se encontrava a Universidade recentemente transferida, e formula então este voto (vide A. Costa Ramalho 1994: $135)$. 
Inegavelmente, um lugar de relevo é dado à educação por D. Diogo de Sousa. Quer pelas funções que desempenha, quer como teólogo e homem de letras, vai ter um papel importante na nova orientação do ensino em Portugal.

No seu ardor pedagógico e teológico, o Prelado bracarense contribuiu para criar o ambiente propício às ideias reformadoras de D. João III, na década de trinta do século XVI, em várias cidades do país e designadamente em Coimbra. Para esta cidade do Mondego transferiu o monarca a Universidade, em 1537, quatro anos após a morte de D. Diogo de Sousa, e nela fundou o Colégio das Artes, em 1548, que lhe deu a maior celebridade, nacional e internacional.

Numa palavra, homem culto do seu tempo, D. Diogo de Sousa governa, temporal e espiritualmente, a sua arquidiocese até à data da sua morte, em 18 de Junho de 1532. Preocupado em instruir e reformar o clero, em alfabetizar o povo, de acordo com os padrões da cultura europeia, interessado na modernização da sua diocese e do seu país pela valorização da educação e da instrução, pela dignificação do papel dos professores e dos eclesiásticos, mentores de uma sociedade renovada, empenhado em institucionalizar o ensino na sua diocese, a nível elementar e superior, funda um colégio universitário na cidade primaz, o Colégio de S. Paulo. Organiza uma ratio studiorum, estatutos próprios, e providencia a construção de instalações, adequadas ao seu funcionamento - prova irrefutável do firme propósito da concretização do seu ambicioso projecto.

Surpreendeu-o a morte antes de ter realizado cabalmente a sua obra educativa. Mas os seus alicerces eram já sólidos e serviram de base aos projectos que iriam empenhar os seus sucessores ${ }^{77}$.

Um tal príncipe, "primeira cabeça", no sentido etimológico, ratio condutora de uma comunidade, com a sua virtude e sabedoria, nobilitas et potentia, será comparável ao sol que a todos ilumina e vivifica - como ilustra a divisa sobreposta ao dossel do desenho preparatório do "Grande

${ }^{77}$ Refira-se designadamente o Cardeal D. Henrique, que engrandeceu com mestres de renome o Colégio de São Paulo, e - após os arcebispados de D. Diogo da Silva e D. Frei Baltazar Limpo - Frei Bartolomeu dos Mártires, o Arcebispo metropolita que, em ambiente de Contra-Reforma, o entregou a 12 de Abril de 1559 à jurisdição dos Jesuítas, a quem D. João III confiara já em 1555 o monopólio do ensino em Portugal. 
Carro triunfal de Maximiliano I", da autoria de Albert Dürer ${ }^{78}$, e que frei Heitor Pinto virá a traduzir, por estas palavras:

"O bom príncipe e prelado é um sol comum a todos, que vigia sobre seu povo com muitos olhos, estando sempre no meio como o Sol que está no meio dos sete planetas ${ }^{79}$.

É esta imagem do Rector christianus, "principe umanizzato" do Renascimento, "uomo universale" que se afirma pelo seu ideal de excelência humana ${ }^{80}$, pela função que exerce no seu governo, non praeesse sed prodesse ao modo agostiniano, e por toda uma estética do poder, de vincada personalização, que é inerente à sua figura - manifestada na observância de um rigoroso cerimonial, marca dos novos tempos, de que são exemplo as celebrações da gesta lusa junto à Cúria Romana ${ }^{81}$.

${ }^{78}$ Uma análise pormenorizada dos elementos simbólicos deste desenho preparatório do grande Carro Triunfal de Maximiliano encontra-se in Nair Soares 1994: 191-198. 173.

${ }^{79}$ Frei Heitor Pinto, Imagem da vida cristã, "Diálogo da Justiça", cap. V:

${ }^{80}$ Este ideal de excelência humana atinge-se pela sabedoria que assenta no convívio diuturno da Sagrada Escritura, dos Padres da Igreja e dos autores clássicos, de que é exemplo Erasmo. A Retórica e a Filosofia - que competiam pelo primeiro lugar, no campo da cultura e da educação - vão ser postas ao serviço do Cristianismo, pelo que se pode falar de retórica e filosofia cristãs - bem documentadas nos autores da Patrística. Se Platão, nas Leis, deriva a paideia do nous divino, a educação filosófica grega oferece uma analogia completa com a teologia cristã; além disso, no Renascimento, o ensino dos diferentes ramos do saber, da enkyklios paideia, herança da época helenística, prepara para a Teologia, a rainha das ciências - como afirmam, desde Cataldo, as orações de sapiência, proferidas na Universidade e no Colégio das Artes, com relevo especial para a de André de Resende de 1534 - verdadeiro manifesto humanista antes da ContraReforma e da entrada da Inquisição em Portugal, em 1536 - pronunciada na Universidade, em Lisboa, antes da sua tranferência para Coimbra, em 1537.

${ }^{81}$ São exemplos o De regis et boni principis officio de Diomede Carafa (ca de 1480), o Principis Diatyposis de Baptista Seccus Platina (ca de 1481, o De regno et regis institutione de Francesco Patrizi (entre 1481e 1484), o De maiestate de Giuniano Majo (ca. 1492), o De principe de Giovane Pontano (ca de 1503), o De officiis principis de Poggio Bracciolini (1504), Il Cortegiano de Baldassare Castiglione (1528) e mesmo, na sua radical singularidade, fora de todo o modelo, 
D. Diogo de Sousa - contemporâneo de Erasmo, Thomas More, Lefèvbre d'Étaples e Josse Clichtove, de Savonarola e Maquiavel, de Leonardo da Vinci e Miguel Ângelo, de Marsilio Ficino, Giovanni Pico della Mirandola e Angelo Poliziano, testemunha da fermentação da Reforma, das guerras de religião e da crise do papado - afirma-se como membro activo da reforma moral, espiritual, intelectual e social do clero e do povo, erguendo bem alto a imagem da Igreja milenar, configurando-a, no seu ministério apostólico, com o Cristo Ressuscitado no seu maior esplendor.

Arcebispo e Senhor de Braga, canonista e teólogo, D. Diogo de Sousa soube imprimir, de forma singular, com a sua uirtus et litterae, o génio cultural do Renascimento na cidade dos homens, a caminho da cidade de Deus.

\section{Referências Bibliográficas}

Albuquerque, Martim de (ed.) (1988), Orações de obediência, séculos XV $a X V I I$. Tradução portuguesa de Miguel Pinto de Meneses, in 10 vols., Lisboa.

AlmeIDA, Fortunato de (1968), História da Igreja em Portugal. Nova edição preparada e dirigida por Damião Peres, 4 vols, Porto-Lisboa.

Alves, Ana Maria (s. d. ), As entradas régias portuguesas. Uma visão de conjunto, Lisboa.

Antonetti, Pierre (1991), Savonarola le Prophète désarmé, Paris.

Arnaut, Salvador Dias (1993), "O Infante D. Pedro, Senhor de Penela", Biblos 49: 173-217.

Artur Anselmo (1981), Origens da Imprensa em Portugal, Lisboa.

Balavorne, Claudie (1983), Les Éclogues d'Henrique Caiado ou L'Humanisme portugais à la conquête de la poesie neo-latine. Texte présenté, traduit et commenté. Lisboa-Paris.

BataIllon, Marcel (1974), Études sur le Portugal au temps de l'Humanisme. Paris.

BorN, Lester K. (1928), "The perfect prince: a study in thirteenth and fourteenth century ideals", Speculum 3: 470-504.

Il principe de Maquiavel (ms. 1513) - que pretende "escrever coisa úteis" e ter como método "seguir a verdade efectiva das coisas e não a ideia que delas se faz" (cap. 15). 
O Arcebispo de Braga D. Diogo de Sousa "Principe Umanizzato" do Renascimento e o seu Projecto Educativo Moderno

Caiado, Henrique: Henrici Caiadi et Syluae et Epigrammata (1501), Bononiae.

Camões, José (ed.) (2002), Obras de Gil Vicente, 2 vols., Lisboa.

Carvalho, Joaquim de (1950), "Pedro Nunes, mestre do Cardeal Infante D. Henrique", A cidade de Évora 21-22: 1-13.

Codoñer, C. (ed.) (1994), Antonio de Nebrija: Edad Media y Renacimiento. Salamanca.

Costa, Avelino de Jesus (1961), "D. Diogo de Sousa, novo fundador da cidade de Braga", Distrito de Braga, Ano I, 2-4: 477-533.

Costa, Avelino de Jesus (1993), "D. Diogo de Sousa novo fundador de Braga e grande Mecenas da cultura", in Homenagem à Arquidiocese Primaz nos 900 anos da dedicação da catedral, Lisboa: 17- 119.

Coutinho, Jorge (coord.) (2006), D. Diogo de Sousa e o seu tempo. No V centenário do início da sua missão como Arcebispo de Braga (15051532). Braga, 18-20 de Novembro de 2005. Actas, Braga.

Cunha, Dom Rodrigo da (1989), Historia Ecclesiastica dos Arcebispos de Braga e dos Santos Varões illustres, que floreceram neste Arcebispado, Segunda Parte, Em Braga por Manoel Cardozo impressor, Anno 1635. Ed. Fac-similada de José Marques, Braga. Cf. Marques José.

Delumeau, Jean (1997), Mil anos de felicidade. Uma história do paraíso. Trad. port., Lisboa (ed. original, Paris, 1995).

Deswarte, Sylvie (1993), "Un âge d' Or. La gloire des Portugais à Rome sous Jules II et Léon X", in Humanismo Português na época dos Descobrimentos (Actas do Congresso internacional - Coimbra, 9-12 de Outubro de 1991), Coimbra, 1993.

Dias, J. S. da Silva (1960), Correntes de sentimento religioso em Portugal (Séculos XVI a XVIII), 2 vols. Coimbra.

DiAs, J. S. da Silva (1972), "Braga e a cultura portuguesa do Renascimento". separata de Philosophica Conimbricensia. Revista de Filosofia e cultura Portuguesa 1: 1-98.

Ferreira, Monsenhor J. Augusto (1931), Fastos Episcopais da Igreja primacial de Braga, II. Braga.

GAuthier, R.-A., O. P. (1951), Magnanimité. L'idéal de la grandeur dans la philosophie païenne et dans la théologie chrétienne. Paris.

Humanismo Português na época dos Descobrimentos (Actas do Congresso internacional - Coimbra, 9-12 de Outubro de 1991), Coimbra, 1993.

LoPes, José Manuel Martins (2002), O projecto educativo da Companhia de Jesus. Dos Exercícios Espirituais aos nossos dias. Braga. 
Machado, José Barbosa (2006), Constituições de D. Diogo de Sousa. Introdução, edição semidiplomática e lematização. Vila Real.

Markus, R. A. (1986), "Gregory the Great's Rector and his genesis" in J.

Fontaine, R. Gillet, S. Pellistrandi, Grégoire le Grand, in Actes du Colloque de Chantilly (le 15-19 september 1982). Paris: 138-141.

Marques, A. J. (1966), "Portugueses nos cláustros salmantinos do século XV”, Revista Portuguesa de Filosofia 19: 167-186.

Marques, José (ed.) (1989), Historia Ecclesiastica dos Arcebispos de Braga. Vide supra Cunha, Dom Rodrigo da.

Marques, José (1997), "O senhorio de Braga no século XV. Principais documentos para o seu estudo", Bracara Augusta 46: 3-143.

Martins, J. V. de Pina (1989), Humanisme et Renaissance de l'Italie au Portugal: les deux regards de Janus, Lisboa-Paris.

Massaut, J.-P. (1968), Josse Clichtove, L'humanisme et la réforme du clergé, 2 vols, Paris.

Maurício, Rui (2000), O Mecenato de D. Diogo de Sousa, Arcebispo de Braga (1505-1532), 2 vols. Leiria.

Mir, Gabriel Codina (1968), Aux sources de la pédagogie des Jésuites. Le "Modus Parisiensis". Roma: 99-190.

OsóRIO, Jerónimo, HIERONYMI OSORI LUSITANI Episcopi Algarbiensis Opera omnia, Hieronymi Osorii nepotis Canonici Eborensis diligentia. In unum collecta, et in Quattuor volumina distributa. Ad Philippum I Portugaliae regem inuictissimum. Romae, Ex Bibliotheca Georgij Ferrarij MDXCII.

Ramalho, A. da Costa (1994, $2^{\mathrm{a}}$ ed.), Antologia de Latim Renascentista em Portugal. Lisboa.

Ramalho,A.da Costa(1997, $2^{\mathrm{a}}$ ed.), Estudos sobre a época do Renascimento. Lisboa ( $1^{\text {a }}$ ed. 1969 , Coimbra).

Ramalho, A. da Costa (2010), Epístolas. I Parte, Lisboa.

Rebelo, Diogo Lopes (1951), Do governo da república pelo rei (De republica gubernanda per regem). Reprodução fac-similada da edição de 1496. Introdução e notas de Artur Moreira de Sá. Lisboa

ReIs, Pe. António P. dos (1745), Corpus Illustrium Poetarum Lusitanorum qui latine scripserunt, 7 vol., Lisboa.

Renaudet, A. (1916, 2 $2^{\mathrm{a}}$ ed. 1953), Préréforme et humanisme à Paris, pendant les premières guerres d'Italie, 1494-1517. Paris.

RESENDE, André de (1956, ed.), Oração de sapiência (L. Andreae Resendii Lusitani Oratio pro rostris pronunciata in Olisiponensi Academia 
Calendis Octobribus MDXXXIIII). Tradução de Miguel Pinto de Meneses. Introdução e notas de A. Moreira de Sá. Lisboa.

Senellart, Michel (2006), As artes de governar, trad. port., São Paulo.

SoAREs, Nair N. C. (1993), "A Virtuosa Benfeitoria, o primeiro tratado de educação de príncipes em português", Biblos 69 - Actas do Congresso Comemorativo do $6^{\circ}$ Centenário do Infante D. Pedro (Coimbra, de 25 a 27 de Novembro de1992), Coimbra: 289-314.

Soares, Nair N. C. (1994), O Príncipe ideal no século XVI e a obra de D. Jerónimo Osório. Coimbra.

Soares, Nair N. C. (2009), "A Casa de Vila Real e o Primeiro Humanismo Português", in Tendências da Literatura. Do Classicismo ao Manei rismo e ao Barroco e sua projecção na actualidade, vol. II, Vila real, UTAD (e ainda no site Letras \& Letras, Universidade do Minho, 2009).

Thurot, Ch. (1850), De l'organisation de l'enseignement dans l'Université de Paris au Moyen Âge. Paris.

Torres, Amadeu (2006), "D. Diogo de Sousa e o contexto cultural do Renascimento" in Jorge Coutinho (coord.), D. Diogo de Sousa e o seu tempo. No V centenário do início da sua missão comoo Arcebispo de Braga (1505-1532) Braga: 35-44; Idem, "D. Diogo de Sousa metropolita de Braga na Europa do Renascimento", Humanidades 2006: 493-503; Idem, "D. Diogo de Sousa no contexto cultural do Renascimento", Humanitas 58 (2006) 291-301.

Verdelho, Evelina (ed. ) (1994), Livro das Obras de Garcia de Resende. Edição crítica, estudo textológico e linguístico. Lisboa. 